\title{
Paracetamolforgiftninger etter innføring av ny salgsordning
}

\begin{abstract}
Sammendrag
Bakgrunn. Sykelighet og dødelighet av paracetamolforgiftning er lav i Norge sammenliknet med $\mathrm{i}$ land med liberal omsetning av paracetamol. Etter innføringen av salg av reseptfrie legemidler utenom apotek (LUA-ordningen) i 2003 har paracetamol $i$ inntil $10 \mathrm{~g}$ pakninger vært tilgjengelig i dagligvarehandelen. Vi har sett på forekomst, alvorlighetsgrad og dødelighet av paracetamolforgiftninger før og etter innføringen av ordningen.
\end{abstract}

Materiale og metode. Forekomst av paracetamolforgiftning er studert på grunnlag av sykehusinnleggelser med paracetamoloverdose ved tre utvalgte sykehus, og Giftinformasjonens henvendelsesstatistikk. Vurdering av alvorlighetsgrad er basert på grad av leverpåvirkning hos pasienter innlagt i sykehus, inntatt dose ved henvendelsene til Giftinformasjonen og antall pasienter vurdert for levertransplantasjon. Data vedrørende dødelighet er hentet fra Dødsårsaksregisteret.

Resultater. Antall sykehusinnleggelser med paracetamoloverdose ved de tre sykehusene har ikke økt etter innføring av salg av reseptfrie legemidler utenom apotek. Antallet henvendelser til Giftinformasjonen om paracetamolinntak har økt. Omfanget av alvorlige paracetamolforgiftninger kan være $ø$ kende, men dødeligheten av slik forgiftning ser ikke ut til å ha økt etter innføring av denne ordningen.

Fortolkning. Det er ikke holdepunkter for at antall paracetamolforgiftninger eller dødsfall etter disse har økt etter innføring av salg av reseptfrie legemidler utenom apotek. Andelen pasienter med leverpåvirkning, og antall pasienter vurdert for levertransplantasjon kan være økende. Forgiftningsbildet med paracetamol bør overvåkes videre.
Christian Haga

chh@helsedir.no

Berit Muan

Avdeling giftinformasjon

Helsedirektoratet

\section{Monica Cheung}

Avdeling for farmasøytisk biovitenskap

Farmasøytisk institutt

Universitetet i Oslo

\section{Mariann Lyngra}

Nyremedisinsk avdeling

Medisinsk avdeling

Akershus universitetssykehus

\section{Carl Erik Strømsæther}

Nyreseksjonen

Medisinsk avdeling

Sykehuset i Østfold

\section{Olav Lutro}

Infeksjonsmedisinsk seksjon

Medisinsk avdeling

Haukeland universitetssykehus

\section{Erik Andrew}

Avdeling giftinformasjon

Helsedirektoratet

Paracetamolforgiftning er et betydelig problem i mange vestlige land. I Storbritannia er denne type forgiftning involvert i 100-200 dødsfall årlig (1). I Norden har Danmark utpekt seg med et relativt høyt antall dødsfall av paracetamolforgiftning, inntil 1995 gjennomsnittlig ni dødsfall per år (2). Felles for Danmark og Storbritannia er at reseptfri paracetamol tidligere har vært tilgjengelig i store pakningsstørrelser. I et forsøk på å få ned antall dødsfall har flere land de siste 10-12 årene begrenset pakningstørrelsen for reseptfri paracetamol.

Ifølge en undersøkelse av Bøe og medarbeidere var det i Norge i perioden 1990-98 i gjennomsnitt 1-2 dødsfall og ca. 500 sykehusinnleggelser per år grunnet paracetamolforgiftning (3). Mens man i mange land de siste årene har innført restriksjoner på salg av reseptfri paracetamol, har man i Norge valgt å øke tilgjengeligheten. Før 1.11. 2003 var paracetamol kun tilgjengelig i apotek, men etter innføringen av ordningen med salg av reseptfrie legemidler utenom apotek (LUA-ordningen), ble paracetamol tillatt solgt også ved andre utsalgssteder.

I denne studien ønsket vi å se om økt tilgjengelighet har sammenfalt i tid med endringer i forekomst, alvorlighetsgrad og dødelighet av paracetamolforgiftninger.

\section{Materiale og metode}

Vi har belyst problemstillingen ved å studere perioden 2001-02 (før innføringen av LUAordningen) og perioden 2005-06 (etter innføringen av LUA-ordningen) når det gjelder sykehusinnleggelser, dødsfall, levertransplantasjoner, serum-paracetamolanalyser og henvendelser til Giftinformasjonen. Vi har også studert salgsstatistikk for paracetamol i disse to periodene.

De ti sykehusene som ifølge Norsk pasientregister (NPR) hadde flest pasienter innlagt med diagnosen forgiftning (T4n-T65 og F100-F190, med 0 som fjerde tegn) i 2006 ble kontaktet og invitert til å være med i studien. Av disse var det kun Akershus universitetssykehus, Haukeland universitetssykehus og Sykehuset i Østfold, avdeling Fredrikstad (senere omtalt som Sykehuset Fredrikstad) som hadde mulighet til å delta. Fra sykehusenes pasientadministrative datasystemer ble det hentet lister over pasienter utskrevet med ICD-10 diagnose T4n (forgiftning med terapeutiske legemidler og biologiske substanser) og/eller T50.9 (forgiftning med andre og uspesifiserte legemidler og biologiske substanser) som hoved- eller bidiagnose. Ved Sykehuset Fredrikstad var det papirjournaler for årene 2001-02. For å begrense antall journaler som måtte gjennomgås manuelt, valgte vi å begrense søket til de tilfellene der det var foretatt serum-paracetamolmåling. Alle aktuelle epikriser ble gjennomlest, og sykehusinnleggelser der paracetamolinntak spesifikt var omtalt ble identifisert. Relevante opplysninger vedrørende disse pasientenes sykehistorie ble hentet fra pasientjournalene og registrert på fastlagt skjema. Pasienter som kun hadde inntatt paracetamol kombinasjonspreparater eller som kun hadde inntatt en døgndose (3 g) paracetamol eller mindre, ble ekskludert. Data som ble registrert var demografiske data, informasjon

\section{Hovedbudskap}

- Antall henvendelser til Giftinformasjonen om paracetamoloverdose har økt betydelig etter at paracetamol ble tillatt solgt utenom apotek

- Antall sykehusinnleggelser med paracetamolforgiftning ser ikke ut til å ha økt

- Antall paracetamoldødsfall ser ikke ut til å ha økt, men andelen av alvorlige paracetamolforgiftninger kan være $ø$ kende 
Tabell 1 Antall innleggelser med paracetamoloverdoser og totalt antall innleggelser ved somatiske avdelinger før og etter innføringen av salg av reseptfrie legemidler utenom apotek (LUAordningen)

\begin{tabular}{llllcc} 
& & Antall & Antall & Endring & \\
Sykehus & Type innleggelser & $2001-02$ & $2005-06$ & $(\%)$ & P-verdi \\
Akershus universitets- & Paracetamoloverdoser & 73 & 79 & +21 & - \\
sykehus & Innleggelser & 66061 & 86923 & +32 & \\
Haukeland universitets- & Paracetamoloverdoser & 88 & 92 & +5 & - \\
sykehus & Innleggelser & 130014 & 153628 & +18 & \\
Sykehuset Fredrikstad & Paracetamoloverdoser & 38 & 57 & +50 & - \\
& Innleggelser & 83161 & 92432 & +11 & \\
\hline Totalt & Paracetamoloverdoser & 199 & 228 & +15 & 0,68 \\
& Totalt antall innleggelser & 279236 & 332983 & +19 & \\
& & & & &
\end{tabular}

Tabell 2 Antall pasienter med leverpåvirkning blant pasienter innlagt med paracetamoloverdose i perioden før og etter innføringen av salg av reseptfrie legemidler utenom apotek (LUA-ordningen). Angitt i parentes er totalt antall innleggelser med paracetamolforgiftning ved de tre sykehusene i de to periodene (tab 1)

\begin{tabular}{ccc} 
& ALAT $>3 \times$ referanseområdet & ALAT $>1000 \mathrm{U} / \mathrm{l}$ \\
$2001-02$ & $5(199)$ & $3(199)$ \\
\hline $2005-06$ & $12(228)$ & $11(228)$
\end{tabular}

Tabell 3 Antall serum-paracetamolanalyser utført ved utvalgte sykehus i perioden før og etter innføringen av salg av reseptfrie legemidler utenom apotek (LUA-ordningen). Angitt i parentes er totalt antall innleggelser med en forgiftningskode (T4n-T65, F10-F19 med 0 som fjerde tegn) ved de tre sykehusene som deltok i studien

\begin{tabular}{lcccc} 
& $2001-02$ & $2005-06$ & Endring (\%) & P-verdi \\
Akershus universitetssykehus & $1004(926)$ & $1132(1$ 149) & +13 & - \\
\hline Sykehuset Fredrikstad & $1124(1137)$ & $1527(1259)$ & +36 & - \\
\hline Haukeland universitetssykehus & $1592(1008)$ & $1543(1446)$ & -3 & - \\
Sykehuset i Vestfold & 1072 & 1000 & -7 & - \\
\hline Sykehuset Buskerud & 1091 & 1282 & +18 & - \\
St. Olavs hospital & 459 & 640 & +39 & - \\
Sykehuset Telemark & 234 & 324 & +39 & - \\
Aker universitetssykehus & 456 & 641 & +41 & - \\
\hline Sum & 7032 & 8089 & +15 & 0,042 \\
\hline
\end{tabular}

om paracetamolinntaket, type paracetamolpreparat og kliniske tegn på leverpåvirkning. Leverpåvirkning ble definert som ALAT > 3 ganger øvre referanseområde, tilsvarende $>135 \mathrm{U} / \mathrm{l}$ for kvinner og $>210 \mathrm{U} / \mathrm{l}$ for menn, leverskade som ALAT $>1000 \mathrm{U} / \mathrm{l}(4,5)$. Antall innleggelser i somatiske avdelinger uavhengig av diagnose ble brukt som kontroll på eventuell endring i sykehusets nedslagsfelt.

Liste med informasjon om dødsfall kodet med ICD-10-koden T39.1 (forgiftning med 4-aminofenolderivater) i periodene 2001-02 og 2005-06 ble, etter søknad, ekstrahert fra Dødsårsaksregisteret, Statistisk sentralbyrå. ICD-10-koden T39.1 innbefatter kun paracetamol som registrert legemiddel i Norge. Dataene fra Dødsårsaksregisteret inneholdt informasjon om dødsår, dødssted, underliggende dødsårsak og tilleggsdiagnoser. På bakgrunn av denne informasjonen ble det vurdert om paracetamolforgiftning var sannsynlig hovedårsak til dødsfallet. cetamolforgiftning ut fra inntatt dose, serumparacetamolnivåer og eventuelle kliniske tegn og symptomer (6).

Salgsstatistikk for paracetamol for perioden 2001-06 ble innhentet fra Folkehelseinstituttet $(7,8)$. Totalt salg av reseptfrie versus reseptbelagte pakninger og utviklingen i andelen solgt utenom apotek etter LUA-ordningen ble studert nærmere.

Prosjektet ble godkjent av Regional etisk komité Sør-Øst. Dispensasjon fra taushetsplikten ble innhentet fra Helsedirektoratet, og det ble innhentet konsesjon fra Datatilsynet for tidsbegrenset behandling av personopplysninger.

\section{Statistikk}

Det ble benyttet khikvadrattest ved statistisk beregning av data fra sykehusinnleggelser og fra Giftinformasjonen. T-test for par ble benyttet på data for serum-paracetamolanalyser. $5 \%$ ble valgt som signifikansnivå. GraphPad Prism versjon 4.01 ble benyttet for de statistiske analysene.

\section{Resultater}

Ved søk på diagnosekodene T4n og/eller T50.9 og samtidig opplysninger om paracetamolinntak ble 622 pasienter identifisert. 185 av pasientene hadde utelukkende inntatt reseptbelagte kombinasjonspreparater, og ti pasienter hadde inntatt mindre enn maksimal terapeutisk døgndose (3 g). Disse pasientene ble ekskludert. 427 pasienter med paracetamoloverdosering ble inkludert i studien.

Økningen i paracetamoloverdoser var ikke signifikant forskjellig fra økningen i totalt antall innleggelser $\mathrm{i}$ alle somatiske avdelinger $(p=0,68)$ (tab 1$)$. Av de pasientene som ble innlagt med paracetamoloverdose, var det en økning i antall pasienter som fikk leverpåvirkning og leverskade (tab 2).

Totalt ble det i periodene 2001-02 og 2005-06 identifisert 27 dødsfall der paracetamolforgiftning var en av diagnosene i dødsmeldingen. Basert på diagnosesettingen i dødsmeldingen ble åtte av dødsfallene vurdert i liten grad å være forårsaket av paracetamol. I de resterende 19 tilfellene ble paracetamol vurdert i vesentlig grad å ha bidratt til dødsfallet. Av disse 19 dødsfallene skjedde 11 i perioden 2001-02 og åtte i perioden 2005-06. Dødssted for de 19 dødsfallene var kodet som «sykehus» i ti tilfeller, «utenfor institusjon» i seks tilfeller, «uoppgitt» i to tilfeller og «syke-/aldershjem» i ett tilfelle.

I perioden 2001-02 ble fire pasienter utredet med tanke på transplantasjon som følge av paracetamolindusert leversvikt. Ingen av disse pasientene ble transplantert. I perioden 2005-06 ble totalt ti pasienter utredet med hensyn på levertransplantasjon. Tre av disse ble transplantert, og to overlevde.

Vi mottok data på utførte analyser av serum-paracetamolkonsentrasjon fra åtte av de ti sykehusene som ble forespurt (tab 3).

Antall henvendelser til Giftinformasjonen angående paracetamolinntak viste en økning 
fra perioden 2001-02 til perioden 2005-06 (tab 4).

Figur 1 viser utviklingen i omsetning av paracetamol. Salget økte fra 21,2 DDD/ 1000 innbyggere i 2001 til 27,3 DDD/1 000 innbyggere i 2006. Dette skyldes en økning i salget av reseptbelagte pakninger, mens omsetningen av reseptfrie pakninger har holdt seg stabilt i perioden. Etter 2003 er imidlertid en stadig større andel av reseptfrie pakninger blitt solgt utenom apotek.

\section{Diskusjon}

Både antall henvendelser til Giftinformasjonen (tab 4) og antall utførte serum-paracetamolanalyser (tab 3) har økt etter innføringen av salg av reseptfrie legemidler utenom apotek, mens antall sykehusinnleggelser med paracetamoloverdose ikke har økt ved de tre studerte sykehusene (tab 1 ).

Økningen i henvendelser til Giftinformasjonen angående inntak av paracetamol har ingen opplagt forklaring. Toksiske grenser og behandlingsregimet for paracetamolforgiftning har vært uforandret i Norge i de to periodene. Giftinformasjonen har også vært like tilgjengelig for konsultasjon i de to periodene. Økt bruk av reseptpliktig paracetamol, og eventuelt økt feilbruk av paracetamol kan være forklaringer bak økningen i antall henvendelser. Økningen i totalt antall henvendelser angående paracetamol skyldes delvis en økning i henvendelser fra sykehus. Dette kan ha flere årsaker. Økt kompetanse blant de ansatte ved Giftinformasjonen på grunn av lengre erfaring og liten utskifting av ansatte i perioden 2001-06 kan ha bidratt til at helsevesenet i større grad har konferert med Giftinformasjonen. Kravet til å dokumentere vurderinger og behandlingstiltak har vært økende i sykehus de siste årene, og kan også ha bidratt til flere henvendelser fra sykehusene.

Det er rimelig å se økningen i henvendelser der det er fare for alvorlig forgifting i sammenheng med økningen i antall henvendelser fra sykehus, da disse pasientene normalt blir innlagt i sykehus. Sykehus som har pasienter med alvorlig paracetamolforgiftning, vil ofte kontakte Giftinformasjonen gjentatte ganger gjennom forgiftningsforløpet. Dette medfører at Giftinformasjonen registrerer samme forgiftningstilfellet flere ganger, og dette kan bidra til en dobbelt registrering.

Andelen av paracetamolinntak som av Giftinformasjonen vurderes som «fare for alvorlig forgiftning» er høy sammenliknet med andelen alvorlige forgiftninger i sykehus. Grunnen til dette er at Giftinformasjonens vurdering gjøres på bakgrunn av inntatt dose, uten hensyn til effekt av eventuell behandling.

Økningen i antall serum-paracetamolanalyser har trolig en annen årsak enn en økning i antall paracetamolforgiftninger. Det er et stort avvik mellom antall analyser (tab 3), og antall overdoser ved de tre sykehusene (tab 1). Noe av dette avviket kan forklares ved inntak av kombinasjonsprepa-

Tabell 4 Antall henvendelser til Giftinformasjonen vedrørende inntak av paracetamol i perioden før og etter innføringen av salg av reseptfrie legemidler utenom apotek (LUA-ordningen)

$\begin{array}{rrr}2001-02 & 2005-06 & \text { Endring }(\%) \\ 250 & 579 & +131 \\ 164 & 408 & +149 \\ 858 & 1518 & +77 \\ 66596 & 78010 & +17\end{array}$

rater, samt at det er tatt flere serum-paracetamolmålinger av samme pasient. Selv korrigert for disse faktorene, er avviket mellom overdoser og analyser betydelig. Hvis vi sammenlikner summen av alle forgiftningsinnleggelser ved de tre sykehusene med antall analyser ved de samme sykehusene (tab 3), ser vi at disse tallene er i tilnærmet like store. Det kan tyde på at serum-paracetamolanalyse utføres nærmest rutinemessig på pasienter med mistanke om forgiftning. Antall serum-paracetamolanalyser er således en dårlig indikator på antall paracetamolforgiftninger.

Antall sykehusinnleggelser med paracetamolforgiftninger steg totalt med $15 \%$. Økningen $\mathrm{i}$ antall paracetamolforgiftninger er ikke større enn økningen i innleggelser totalt ved somatiske avdelinger (tab 1). Økningen i antall paracetamolforgiftninger kan forklares ut fra en generell økning i innleggelser, muligens som en følge av utvidelse av dekningsområdet til sykehuset. Når vi ser på tallene fra det enkelte sykehus, skiller Sykehuset Fredrikstad seg ut med større økning i antall paracetamoloverdoser enn de to andre sykehusene. Tallene fra Sykehuset Fredrikstad beheftes imidlertid med en metodisk usikkerhet da dataene for perioden 2001-02 forutsetter at det er gjort en serum-paracetamolanalyse. Antallet serum-paracetamolanalyser ved sykehuset er svært høyt ( $\mathrm{N}=1124)$ i perioden 2001-02 sammenliknet med antall inn- leggelser forårsaket av paracetamolforgiftning $(\mathrm{N}=38)$. Det er derfor rimelig å anta at de aller fleste paracetamoforgiftningene ved Sykehuset Fredrikstad er inkludert i studien. Lokale trender når det gjelder selvskading, og enkeltpasienter som gjentatte ganger forgifter seg, kan også medføre lokal variasjon mellom sykehusene.

Hos de innlagte pasientene er alvorlighetsgraden av forgiftningen vurdert ut fra grad av leverpåvirkning. Antall pasienter som fikk leverpåvirkning økte fra 2001-02 til 2005-06 (tab 2). Tallene er små og vanskelig å tolke, men antyder en mulig økning i alvorlighetsgrad uten at antall forgiftninger har endret seg. Hvis dette er tilfellet, kan det ha flere årsaker. Leverskade forårsaket av paracetamoloverdose skyldes i all hovedsak at pasienter oppsøker helsetjenesten sent i forløpet. Sen innleggelse kan skyldes at pasienten uforvarende har overdosert paracetamol, og først oppsøker lege ved symptomer på leverskade. Mangel på informasjon ved kjøp av paracetamol, og «ufarliggjøring» gjennom salg fra dagligvareforretninger og bensinstasjoner, kan bidra til økt feilbruk av paracetamol. Erfaringsmessig tolker også en del pasienter fravær av symptomer den første tiden etter inntak som et tegn på at inntatt dose ikke var toksisk.

Økningen i antall pasienter som vurderes for transplantasjon, kan være et uttrykk for en økning i antall alvorlige forgiftninger.

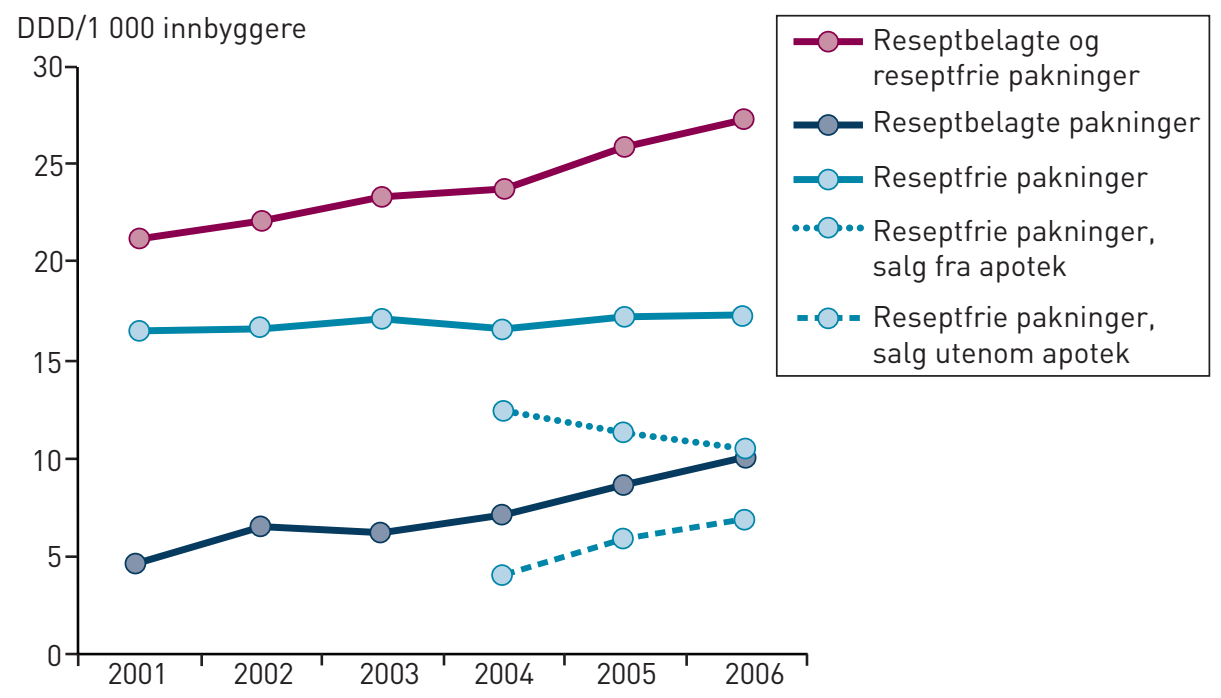

Figur 1 Salg av paracetamol i definerte døgndoser DDD /1 000 innbyggere i tiden 2001-06. For perioden 2004-06 er reseptfritt salg delt $i$ «salg fra apotek» og «salg utenom apotek» 
Økningen kan også være et resultat av økt oppmerksomhet rundt levertransplantasjon som et behandlingsalternativ ved tegn på alvorlig leverskade.

Dødsfall av paracetamolforgiftning ser ikke ut til å ha økt etter innføringen av ordningen med omsetning av reseptfrie legemidler utenom apotek. To av de tre pasientene som ble transplantert i 2005-06 overlevde. Dette kan ha bidratt til færre dødsfall i perioden 2005-06. Dødsfallene som ble identifisert via Dødsårsaksregisteret, er trolig en overestimering av antall dødsfall av paracetamol. Kun ti av de 19 dødsfallene der paracetamol var kodet som en hovedårsak, hadde dødsstedkode «sykehus». På bakgrunn av det vanlige kliniske forløpet av en leversvikt, må det anses som lite sannsynlig at ni av 19 pasienter dør utenfor sykehus (9).

Økt omsetning av paracetamol i perioden 2001-06 skyldes økning i salget av reseptbelagt paracetamol (fig 1). Økt salg av analgetika generelt kan forklare noe av salgsøkningen av paracetamol. Medieomtalen av Vioxx (rofecoxib)-skandalen i 2004-05 kan også ha påvirket omsetningen av reseptpliktig paracetamol.

Studier der man har prøvd å se på sammenhengen mellom endringer i tilgjengelighet og forgiftningsmønster av paracetamol, gir et uklart bilde. Generelt er forgiftningsproblemene mest omfattende der tilgjengeligheten og forbruket er størst (10). På den annen side har det vist seg at etablerte trender med høy forekomst av paracetamolforgiftninger ikke er lette å snu, og effekten av regelendringen i Storbritannia har hatt begrenset effekt på antall og alvorlighetsgrad av paracetamolforgiftninger (1). Samtidig har Canada, i likhet med Norge, økt tilgjengeligheten av paracetamol uten at dette har gitt økning i antall innleggelser med paracetamolforgiftninger $(11,12)$. Felles for flere av studiene, også vår studie, er at det har gått kort tid fra regelendringen trådde i kraft til studien er utført. Til sammenlikning tok det om lag 20 år fra paracetamol ble reseptfritt i Storbritannia til man så økning i antall forgiftninger (9). Det er også mange andre faktorer enn tilgjengelighet som kan påvirke forgiftningsbildet. Metoder som brukes til selvmord og den generelle selvmordsraten endrer seg over tid, og vil kunne påvirke forgiftningsbildet (13).

Det er flere begrensninger ved studien. Dataene fra sykehusinnleggelser er kun fra tre større sykehus, og i hvilken grad disse tre sykehusene er representative for forgiftningssituasjonen i Norge er uvisst. Det har heller ikke vært mulig å skille inntak av reseptbelagt og reseptfritt paracetamol. Vi brukte søk på spesifikke diagnosekoder for å identifisere paracetamolforgiftning. Tidligere studier har pekt på at det forekommer en del feilkoding ved forgiftningsinnleggelser. Det kan derfor ikke utelukkes at noen pasienter innlagt med paracetamolforgiftning ikke er blitt inkludert (14). Det er derimot ingen holde- punkter for at omfanget av feilkoding har endret seg i løpet av de to periodene. Antall pasienter med leverpåvirkning/leverskade, antall pasienter utredet for transplantasjon og antall dødsfall er alle lave. Dette medfører at dataene er vanskelig å tolke, og statistisk beregning blir usikkert. Vurderingen av dødsårsak ble i denne studien basert på koding dødsmeldingen, noe som medfører en grad av usikkerhet. Dersom vi hadde gjennomgått selve dødsmeldingen, kunne vi med større grad av sikkerhet ha vurdert hvorvidt paracetamol bidro vesentlig til dødsfallet.

\section{Konklusjon}

Som tilsiktet med innføringen av salg av reseptfrie legemidler utenom apotek er en betydelig del av salget av reseptfritt paracetamol blitt overført fra apotek til omsetning utenfor apotek uten at det totale salget av reseptfritt paracetamol har økt.

Studien viser en økning i antall henvendelser om paracetamol til Giftinformasjonen, og i antall utførte serum-paracetamolanalyser ved utvalgte sykehus. Antall innleggelser med paracetamoloverdose ved de tre sykehusene og antall dødsfall av paracetamolforgiftning økte ikke i studieperioden. Andelen pasienter med leverpåvirkning/ leverskade, og antall pasienter vurdert for levertransplantasjon viser en økende trend.

Sykelighet og dødelighet av paracetamolforgiftninger er fortsatt lav i Norge. Siden studien er utført kort tid etter endring i tilgjengelighet, bør forgiftningsmønsteret for paracetamol følges i årene som kommer.

Giftinformasjonen har mottatt 80000 kroner i støtte fra Norges Apotekforening for å gjennomføre studien.

\section{Christian Haga (f. 1972)}

er cand.pharm. Han er seniorrådgiver i Helsedirektoratet, Avdeling for Giftinformasjon, har arbeidet ved Giftinformasjonen i ti år. Ingen oppgitte interessekonflikter.

\section{Berit Muan (f. 1960)}

er cand.pharm/dr.scient og avdelingsleder i Avdeling for farmakologi, Klinikk for diagnostikk og intervensjon, Oslo universitetssykehus. Hun var tidligere seksjonssjef ved Giftiformasjonen, Helsedirektoratet, og klinisk forskningsleder i farmasøytisk industri (Nycomed Imaging/Amersham/GE Healthcare) Ingen oppgitte interessekonflikter.

\section{Monica Cheung (f. 1985)}

har mastergrad i farmasi og arbeider som bivirkningsansvarlig i Abbott.

Ingen oppgitte interessekonflikter.

\section{Marianne Lyngra (f. 1976)}

er assistentlege ved nyremedisinsk avdeling Ingen oppgitte interessekonflikter.

\section{Carl Erik Strømsæther}

er pensjonert overlege (fra 1.5. 2011), tidligere overlege ved Nyreseksjonen, Medisinsk avdeling, Sykehuset Østfold, Fredrikstad. Spesalist $\mathrm{i}$ indremedisin og nyresykdommer.

Oppgitte interessekonflikter: Forfatteren har mottatt støtte til kurs og møte fra Roche og Novartis.

\section{Olav Lutro (f. 1973)}

er assistentlege ved Medisinsk avdeling, Haukeland universitetssykehus.

Ingen oppgitte interessekonflikter.

\section{Erik Andrew (f. 1945)}

er m.sci.pharm. og dr.philos. seniorrådgiver ved Giftinformasjonen. Har tidligere vært professor II i farmakologi/toksikologi ved Farmasøytisk institutt, Universitetet i Oslo, tidligere leder av Giftinfomrasjonen og klinisk forskningssjef (Vice President) i Nycomed Imaging. Ingen oppgitte interessekonflikter.

\section{Litteratur}

1. Hawkins LC, Edwards JN, Dargan PI. Impact of restricting paracetamol pack sizes on paracetamol poisoning in the United Kingdom: a review of the literature. Drug Saf 2007: 30: 465-79.

2. Lystbaek BB, Svendsen LB, Heslet L. Paracetamolforgiftning. Ugeskr Læger 1995; 157: 869-73.

3. Bøe GH, Haga C, Andrew E et al. Paracetamolforgiftninger i Norge 1990-2001. Tidsskr Nor Lægeforen 2004: 124: 1624-8.

4. Aakvik R, Jacobsen D. Paracetamolforgiftning forekomst og behandling. Tidsskr Nor Lægeforen 2006; 126: 1731-3.

5. Watkins PB, Kaplowitz N, Slattery JT et al. Aminotransferase elevations in healthy adults receiving 4 grams of acetaminophen daily. A randomized controlled trail. JAMA 2006; 296: 87-93.

6. Helsedirektoratet, avdeling for Giftinformasjon Paracetamol - behandlingsanbefaling ved forgiftning. www.helsebiblioteket.no (15.10.2010).

7. Legemiddelforbruket i Norge 2000-2004. Oslo: Nasjonalt folkehelseinstitutt, 2005

8. Nasjonalt folkehelseinstitutt. Legemiddelforbruket i Norge 2005-2009. www. legemiddelforbruk.no (11.10.2010).

9. Bateman DN, Gorman DR, Bain M et al. Legislation restricting paracetamol sales and patterns of self-harm and death from paracetamol-containing preparations in Scotland. Br J Clin Pharmacol 2006; 62: 573-81.

10. Gunnell D, Hawton K, Murray V et al. Use of paracetamol for suicide and non-fatal poisoning in the UK and France: are restrictions on availability justified? J Epidemiol Community Health 1997 . 51: 175-9.

11. Prior MJ, Cooper K, Cummins P et al. Acetamino phen availability increases in Canada with no increase in the incidence of reports of inpatient hospitalizations with acetaminophen overdose and acute liver toxicity. Am J Ther 2004; 11: 443-52.

12. Myers RP, Li B, Fong A et al. Hospitalizations for acetaminophen overdose: a Canadian populationbased study from 1995 to 2004 . BMC Public Health 2007; 7: 143

13. Baumert J, Erazo N, Ruf E et al. Time trends in suicide mortality vary in choice of methods: an analysis of 145,865 fatal suicide cases in Germany 1991-2002. Soc Psychiatry Psychiatr Epidemiol 2008; 43: 913-9.

14. Muan B, Heyerdahl F, Lindås R et al. Kodepraksis ved forgiftningsdødsfall. Tidsskr Nor Legeforen 2010; 130: 1601-5. 